\title{
Hydrogen Production from the Water-Gas Shift Reaction on Iron Oxide Catalysts
}

\author{
R. Bouarab, ${ }^{1}$ S. Bennici, ${ }^{2}$ C. Mirodatos, ${ }^{2}$ and A. Auroux ${ }^{2}$ \\ ${ }^{1}$ Département de Génie de l'Environnement, Ecole Nationale Polytechnique, 10 Avenue H. Badi, BP 182, El Harrach, \\ 16200 Alger, Algeria \\ ${ }^{2}$ Institut de Recherches sur la Catalyse et l'Environnement de Lyon, UMR 5256, CNRS-UCB Lyon1, 2 Avenue Albert Einstein, \\ 69626 Villeurbanne Cedex, France \\ Correspondence should be addressed to R. Bouarab; rabah.bouarab@enp.edu.dz
}

Received 11 July 2014; Revised 8 September 2014; Accepted 8 September 2014; Published 25 September 2014

Academic Editor: Hicham Idriss

Copyright (C) 2014 R. Bouarab et al. This is an open access article distributed under the Creative Commons Attribution License, which permits unrestricted use, distribution, and reproduction in any medium, provided the original work is properly cited.

Unsupported and supported iron oxide catalysts were prepared by incipient wetness impregnation method and studied in the watergas shift reaction (WGSR) in the temperature range $350-450^{\circ} \mathrm{C}$. The techniques of characterization employed were BET, X-ray diffraction, acid-base measurements by microcalorimetry and in situ diffuse reflectance infrared Fourier transform spectroscopy. $\mathrm{MgO}, \mathrm{TiO}_{2}$, or $\mathrm{SiO}_{2}$ was added in order to (i) obtain a catalyst exempt of chromium oxide and (ii) study the effect of their acidbase properties on catalytic activity of $\mathrm{Fe}_{2} \mathrm{O}_{3}$. X-ray diffraction studies, and calorimetric and diffuse reflectance infrared Fourier transform measurements reveal a complete change in the physicochemical properties of the iron oxide catalyst after $\mathrm{MgO}$ addition due to the formation of the spinel oxide phase. These results could indicate that the $\mathrm{MgFe}_{2} \mathrm{O}_{4}$ phase stabilizes the reduced iron phase, preventing its sintering under realistic WGSR conditions (high $\mathrm{H}_{2} \mathrm{O}$ partial pressures).

\section{Introduction}

Carbon oxide reacts with water and produces, via the reversible and exothermic reaction: $\mathrm{CO}+\mathrm{H}_{2} \mathrm{O}=\mathrm{CO}_{2}+$ $\mathrm{H}_{2}$, carbon dioxide with pure hydrogen. In recent years, this reaction has received considerable interest due to the possibility to reduce a large amount of carbon monoxide from reformed fuels $\left(\mathrm{CO}+\mathrm{H}_{2}\right)$ into additional hydrogen production. This reaction is catalyzed with a large variety of metals and metal oxides like $\mathrm{Fe}[1-3], \mathrm{Cu}[2,4], \mathrm{Au}$ $[2,5,6], \mathrm{Ru}[2,7]$, and $\mathrm{Pt}[8,9]$ and is often performed in two steps to achieve rates for commercial purposes. At lower temperature $\left(150-250^{\circ} \mathrm{C}\right)$ the catalyst of choice is based on copper $\mathrm{Cu}-\mathrm{ZnO}$. The iron oxide-based catalysts, $\mathrm{Fe}_{2} \mathrm{O}_{3}$, are well known in high temperature water-gas shift reaction $\left(350-450^{\circ} \mathrm{C}\right)$ and are generally doped with chromium oxide, $\mathrm{Cr}_{2} \mathrm{O}_{3}$, which prevents the sintering of iron oxide crystallites. Before the high temperature shift catalysts can be used, hematite must be converted to magnetite which is believed to be the active phase. This reduction is carried out with process gas mixtures of hydrogen, nitrogen, carbon oxide, carbon dioxide, and water vapour and is controlled to avoid further reduction of magnetite active material to lower oxides or to metallic iron species. Metallic iron is an active catalyst for the methanation of $\mathrm{CO}$ and the Fischer-Tropsch processes, which is undesirable here, since all generated hydrogen is consumed. To solve this problem, it is suitable to develop iron oxide stable catalysts that would be more difficult to reduce to metallic iron.

Júnior et al. [10] have indicated that the substitution of chromium by vanadium, in the iron oxide based water-gas shift reaction, produced directly the sought active phase. In a recent study, Martos and his coworkers [11] have replaced chromium by molybdenum in magnetite-based catalysts, by using the oxidation-precipitation and wet impregnation methods preparation and concluded that molybdenum increases thermal stability of the magnetite active phase and prevents metallic iron formation during the reaction. 
The oxidation-precipitation method allows obtaining the material directly in the active phase and molybdenum is incorporated into magnetite lattice. Boudjemaa et al. [3] have reported that magnesium could be a good candidate to replace chromium in iron-based catalysts since $\mathrm{Mg}$-rich catalysts are more active than $\mathrm{Cr}$-promoted ones. By adding $\mathrm{MgO}$ to $\mathrm{Fe}_{2} \mathrm{O}_{3}$ [12], it was found that the $\mathrm{Fe}_{2} \mathrm{O}_{3}-\mathrm{MgO}$ basic catalyst is 100 times more active than the acidic catalyst $\mathrm{Fe}_{2} \mathrm{O}_{3} / \mathrm{SiO}_{2}$ and a direct relation between catalytic activity and acid-base properties of catalysts is established.

The catalytic conversion of carbon oxide and water to carbon dioxide and hydrogen via the water-gas shift reaction is established to take place principally through two main types of mechanisms, the regenerative mechanism or the associative mechanism. In the first mechanism the catalyst surface is successively oxidized by $\mathrm{H}_{2} \mathrm{O}$ and reduced by $\mathrm{CO}$ [13]:

$$
\begin{aligned}
& \mathrm{H}_{2} \mathrm{O}+\mathrm{red} \longrightarrow \mathrm{H}_{2}+\mathrm{Ox} \\
& \mathrm{CO}+\mathrm{Ox} \longrightarrow \mathrm{CO}_{2}+\mathrm{Red}
\end{aligned}
$$

In turn, the associative mechanism supposes that the reactants $\mathrm{CO}$ and $\mathrm{H}_{2} \mathrm{O}$ interact to form a reaction intermediate, such as an adsorbed formate adspecies, which then decomposes to $\mathrm{CO}_{2}$ and $\mathrm{H}_{2}$ :

$$
\mathrm{CO}+\mathrm{H}_{2} \mathrm{O} \longrightarrow \text { Formate } \longrightarrow \mathrm{CO}_{2}+\mathrm{H}_{2}
$$

It was proposed in several researches that the formic acid species can be used as an intermediate to represent the formate group produced from the reaction between carbon oxide and water in the WGS reaction $[2,9,13]$ on the following dehydrogenation process:

$$
\mathrm{HCOOH} \longrightarrow \mathrm{CO}_{2}+\mathrm{H}_{2}
$$

The decomposition of formic acid (reaction (3)) to the products of WGS reaction is catalyzed by metals and basic metal oxides.

In this work, we present the results of the effect of acidbase properties created by the support addition oxides on the catalytic activity of $\mathrm{Fe}_{2} \mathrm{O}_{3}$ in the water-gas shift reaction. An associative mechanistic of hydrogen production in the high temperature shift reaction was also developed on iron oxide catalyst.

\section{Experimental}

2.1. Materials Synthesis and Characterizations. $30 \mathrm{wt} \%$ $\mathrm{Fe}_{2} \mathrm{O}_{3}-\mathrm{MO}_{x}$ systems, with $\mathrm{M}$ equal to $\mathrm{Mg}$, Ti, or $\mathrm{Si}$, were prepared by incipient wetness impregnation method. This method consists of adsorbing an adequate aqueous solution of iron nitrate salt $\mathrm{Fe}\left(\mathrm{NO}_{3}\right)_{3} \cdot 9 \mathrm{H}_{2} \mathrm{O}$ onto the selected support $\mathrm{MgO}, \mathrm{TiO}_{2}$, or $\mathrm{SiO}_{2}$. The systems obtained are $30 \mathrm{Fe}-\mathrm{Mg}$, $30 \mathrm{Fe}-\mathrm{Ti}$, and $30 \mathrm{Fe}-\mathrm{Si}$. All these solids were calcined at $400^{\circ} \mathrm{C}$.

The concentration of iron oxide in the solution was controlled to obtain the desired Fe content on $\operatorname{MgO}(5,10$, 20 , and $30 \mathrm{wt} \%)$. It is about $5 \mathrm{Fe}-\mathrm{Mg}, 10 \mathrm{Fe}-\mathrm{Mg}, 20 \mathrm{Fe}-\mathrm{Mg}$, and $30 \mathrm{Fe}-\mathrm{Mg}$, respectively.
$30 \mathrm{Fe}-\mathrm{Mg}$ system was calcined for study needs at $200^{\circ} \mathrm{C}$ and $300^{\circ} \mathrm{C}$. These systems are labeled $30 \mathrm{Fe}-\mathrm{Mg} 400,30 \mathrm{Fe}-$ $\mathrm{Mg} 300$, and 30Fe-Mg200.

The elaborated solids were then characterized by means of techniques of analysis, X-ray powder diffraction, $\mathrm{CO}_{2}$ and $\mathrm{NH}_{3}$ adsorptions calorimetry, and the diffuse reflectance infrared Fourier transform spectroscopy. X-ray diffraction studies were obtained with a Philips PW 1050/81 automated powder goniometer, equipped with a diffracted-beam graphite monochromatic $\mathrm{Cu}\left(\mathrm{K}_{\alpha}\right)$ radiation. $\mathrm{CO}_{2}$ and $\mathrm{NH}_{3}$ adsorptions calorimetry was carried out at $80^{\circ} \mathrm{C}$ after activation under $\mathrm{H}_{2}$ flow at $200^{\circ} \mathrm{C}$. Differential heats of adsorption were measured in a heat flow Setaram HT microcalorimeter linked to a volumetric adsorption system. Successive small doses of $\mathrm{CO}_{2}$ or $\mathrm{NH}_{3}$ were sent over the catalytic surface. From the calorimetric and volumetric data, the differential heats of adsorption versus coverage and the corresponding isotherms are plotted. In situ diffuse reflectance infrared Fourier transform studies were performed on a Nicolet Magna IRTF spectrometer with OMNIC software. The reaction was performed in a high temperature Spectratech cell equipped with a $\mathrm{ZnSe}$ window. A sample was first treated in a flow of $(\sim 35 \mathrm{~mL} / \mathrm{min}) \mathrm{H}_{2}$ at $400^{\circ} \mathrm{C}$ for $30 \mathrm{~min}$ (hightemperature treatment) before each experiment. After this treatment, the sample was cooled under helium and then put in contact with the reacting mixture $\mathrm{CO}+\mathrm{H}_{2} \mathrm{O}$ at increasing temperature from 25 to $450^{\circ} \mathrm{C}$.

2.2. $\mathrm{CO}+\mathrm{H}_{2} \mathrm{O}$ Reaction. Catalytic properties of Fe-only and $\mathrm{Fe}$-supported systems were examined in the reaction of the conversion of carbon oxide to carbon dioxide usually named WGSR between $350^{\circ} \mathrm{C}$ and $450^{\circ} \mathrm{C}$. The reduction treatment was carried for all Fe-based catalysts with a mixture of $\mathrm{H}_{2} / \mathrm{N}_{2}$ at $450^{\circ} \mathrm{C}$ during 60 min with a heating rate of $5^{\circ} \mathrm{C} \cdot \mathrm{min}^{-1}$. The mixtures of reactant gases, $\mathrm{H}_{2} \mathrm{O} / \mathrm{CO}=$ 4.4 at a total flow-rate of $33 \mathrm{~mL} / \mathrm{min}$, and products were periodically analysed on line using a TCD chromatograph which contained two $4 \mathrm{~m}$ carbosieve B columns (1/8 inch, 100 to $200 \mathrm{mesh}$ ). Prior to analysis, the effluent was passed through a water-trap at $0^{\circ} \mathrm{C}$ in order to remove reaction water.

\section{Results and Discussions}

3.1. Fe-Cr Systems. Iron and chromium based catalysts, known generally as high temperature shift catalysts, are active within the temperature range of $350-450^{\circ} \mathrm{C}$. Three methods of preparation of iron-chromium oxides, described obviously in [3], are chosen to study their catalytic activities in WGS reaction. The hydrogen produced via the $\mathrm{CO}+\mathrm{H}_{2} \mathrm{O}$ process at $450^{\circ} \mathrm{C}$ of the Fe-only and $\mathrm{Fe}$ - $\mathrm{Cr}$ synthesized under various preparation methods is presented in Figure 1. The samples were reduced in a mixture of $\mathrm{H}_{2}+\mathrm{N}_{2}$ at $450^{\circ} \mathrm{C}$ during $60 \mathrm{~min}$ before the reaction. The Fe-Cr prepared by substituting Fe by Cr stays almost inactive for all the duration of the study, while $\mathrm{Fe}-\mathrm{Cr}$ prepared by the coprecipitation technique provides the highest values of $\mathrm{H}_{2}$ after 90 min of reaction time and $\mathrm{Fe}-\mathrm{Cr}$ prepared via impregnation method exhibits an intermediate performance. In turn, the Fe-only catalyst presents very high 


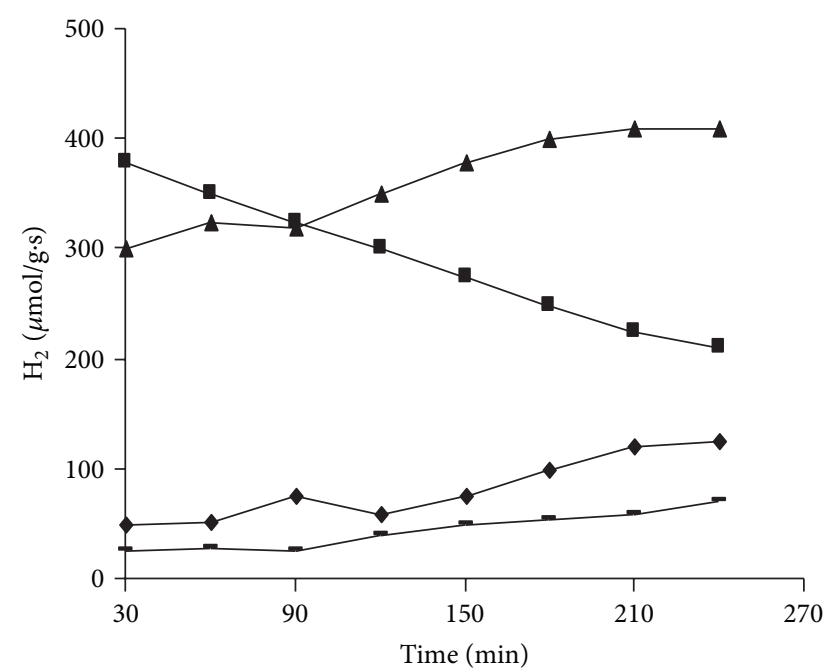

FIGURE 1: Hydrogen generation via WGSR of the calcined and reduced solids prepared by (-) substitution, $(\bullet)$ impregnation, and (ム) coprecipitation methods. (₫) corresponds to $\mathrm{Fe}_{2} \mathrm{O}_{3}$.

initial activity which decreased significantly with the reaction time to values one more active than the promoted catalyst Fe$\mathrm{Cr}$ prepared via impregnation method. This loss of activity and stability can be related to the sintering of the iron oxide phase. It has been proved that the addition of chromium oxide to $\mathrm{Fe}_{2} \mathrm{O}_{3}$ slows the deactivation of the iron oxide [14].

3.2. Fe-Mg Systems. The aim of this part of the study is to promote the iron oxide-based catalyst by replacement of the chromium oxide by $\mathrm{MgO}$ which can be apt to improve the catalytic activity of the intermediate active catalyst, in the occurrence $\mathrm{Fe}-\mathrm{Cr}$ prepared via impregnation method (see Figure 1). Our intent here is for $5 \mathrm{Fe}-\mathrm{Mg}, 10 \mathrm{Fe}-\mathrm{Mg}$, $20 \mathrm{Fe}-\mathrm{Mg}$, and $30 \mathrm{Fe}-\mathrm{Mg}$ or $30 \mathrm{Fe}-\mathrm{Mg} 400,30 \mathrm{Fe}-\mathrm{Mg} 300$, and $30 \mathrm{Fe}-\mathrm{Mg} 200$ catalysts. The WGS reaction results of Fe-Mg catalysts, expressed by the hydrogen production and the Xray diffraction patterns of the magnesium promoted catalyst, are given in Figures 2 and 3, respectively.

Figure 2 shows the effect of magnesium additives to iron oxide-based catalysts on the hydrogen production via the WGS reaction at the temperature range $350-450^{\circ} \mathrm{C}$. The quantity of hydrogen produced increases significantly with the increase of iron oxide content in the following order $5 \mathrm{Fe}$ $\mathrm{Mg}<10 \mathrm{Fe}-\mathrm{Mg}<20 \mathrm{Fe}-\mathrm{Mg}<30 \mathrm{Fe}-\mathrm{Mg}$. The $\mathrm{H}_{2}$ production is also found to increase with the rise of reaction temperature. We have reported in previous works $[3,15]$ that the sample $30 \mathrm{Fe}-\mathrm{Mg}$ produced a spinel oxide phase of type $\mathrm{MgFe}_{2} \mathrm{O}_{4}$ together with a predominant $\mathrm{MgO}$ phase at a temperature of calcination of $400^{\circ} \mathrm{C}$ and presented excellent performance in the WGS reaction. Furthermore, we projected that a decrease in calcination temperature from 400 to $200^{\circ} \mathrm{C}$ would not produce the spinel oxide.

The X-ray diffractograms of pure and Fe-supported 5$30 \mathrm{wt} \% \mathrm{Fe}-\mathrm{Mg}$ solids calcined at $400^{\circ} \mathrm{C}$ and $30 \mathrm{wt} \% \mathrm{Fe}-\mathrm{Mg}$ calcined at 200,300 , and $400^{\circ} \mathrm{C}$ were studied and illustrated by Figure 3. The analysis of XRD patterns reveals that

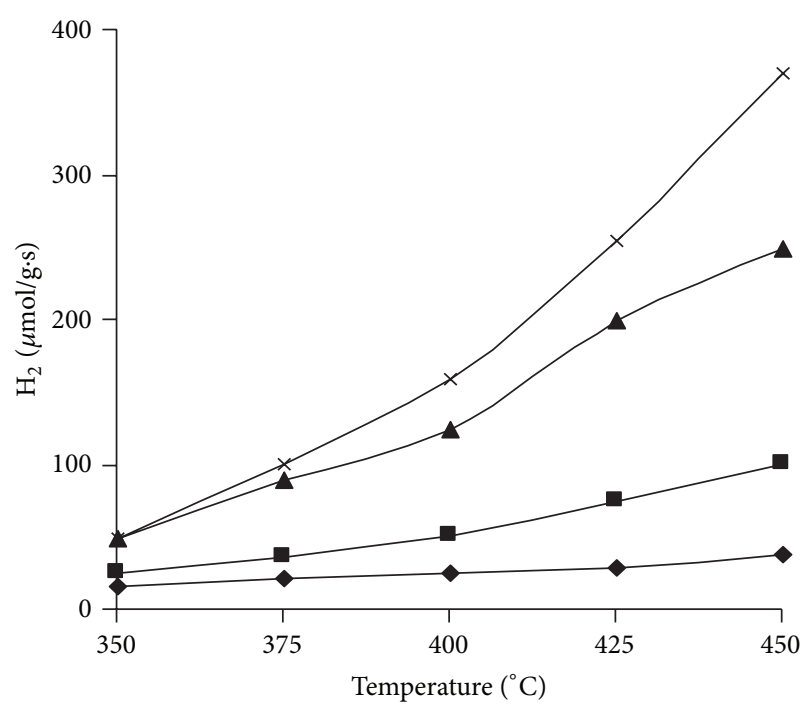

FIGURE 2: Temperature dependence of the $\mathrm{H}_{2}$ generation from WGS reaction of the samples: $(\bullet) 5 \mathrm{Fe}-\mathrm{Mg},(\boldsymbol{\square}) 10 \mathrm{Fe}-\mathrm{Mg},(\boldsymbol{\Delta}) 20 \mathrm{Fe}-\mathrm{Mg}$, and (x) $30 \mathrm{Fe}-\mathrm{Mg}$ after a reduction treatment at $450^{\circ} \mathrm{C}$ during $60 \mathrm{~min}$. Reactant gas mixture, $\mathrm{H}_{2} \mathrm{O} / \mathrm{CO}=4.4$. Total flow-rate of $33 \mathrm{~mL} / \mathrm{min}$.

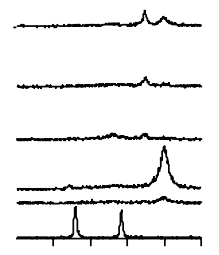

3234363840

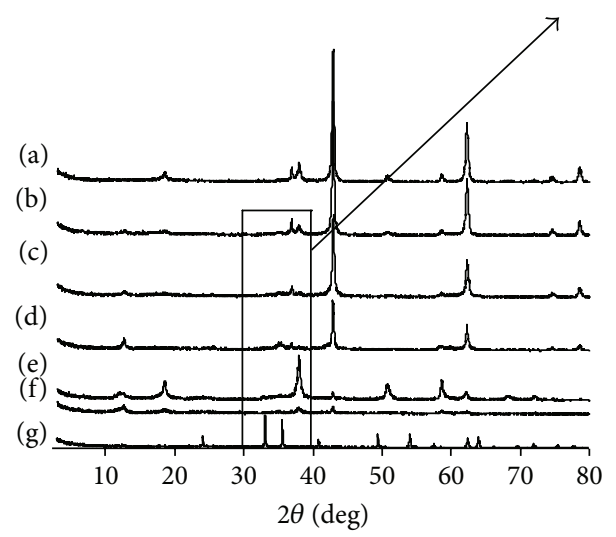

FIGURE 3: X-ray diffraction patterns of the magnesium promoted Fe-Mg catalysts. (a) $5 \mathrm{Fe}-\mathrm{Mg}$, (b) $10 \mathrm{Fe}-\mathrm{Mg}$, (c) $20 \mathrm{Fe}-\mathrm{Mg}$, (d) $30 \mathrm{Fe}-$ $\mathrm{Mg} 400$, (e) 30Fe-Mg300, (f) 30Fe-Mg200, and (g) Fe-only.

the $\mathrm{Fe}_{2} \mathrm{O}_{3}$ crystalline phase was detected in the unsupported solid. Iron oxide did not appear on the Fe-supported solids. By looking at $5-30 \mathrm{wt} \% \mathrm{Fe}-\mathrm{Mg}$ spectra, it appears clearly that the intensity of the principal ray assigned to the $\mathrm{MgO}$ crystalline phase decreases progressively when the iron oxide charge increases by 5 to $30 \mathrm{wt} \%$. At a charge of $30 \mathrm{wt} \% \mathrm{Fe}_{2} \mathrm{O}_{3}$ (spectrum d), the crystalline fraction of $\mathrm{MgO}$ is ostensibly changed by the formation of $\mathrm{MgFe}_{2} \mathrm{O}_{4}$ spinel phase [16]. 
TABLE 1: $S_{\mathrm{BET}}$, XRD, and DRIFT results of the elaborated catalysts.

\begin{tabular}{|c|c|c|c|c|c|c|}
\hline \multirow{2}{*}{ Catalyst } & \multirow{2}{*}{$\begin{array}{l}\text { BET area } \\
\left(\mathrm{m}^{2} \cdot \mathrm{g}^{-1}\right)\end{array}$} & \multirow{2}{*}{ XRD data ${ }^{a, b}$} & \multicolumn{4}{|c|}{ DRIFT wave numbers ${ }^{\mathrm{a}}\left(\mathrm{cm}^{-1}\right)$} \\
\hline & & & $\mathrm{OH}$ band & $\mathrm{CO}$ & OCO species & $\mathrm{CH}$ vibration \\
\hline Fe-only & 25.0 & $\mathrm{Fe}_{2} \mathrm{O}_{3}$ & $-^{c}$ & - & - & - \\
\hline $30 \mathrm{Fe}-\mathrm{Si}$ & 90.7 & $\mathrm{Fe}_{2} \mathrm{O}_{3}, \mathrm{SiO}_{2}$ & - & - & - & - \\
\hline $30 \mathrm{Fe}-\mathrm{Ti}$ & 14.0 & $\mathrm{Fe}_{2} \mathrm{O}_{3}, \mathrm{TiO}_{2}$ & - & $2170-2080$ & - & - \\
\hline $30 \mathrm{Fe}-\mathrm{Mg}$ & 02.2 & $\mathrm{MgFe}_{2} \mathrm{O}_{4}, \mathrm{MgO}$ & $\begin{array}{l}3570\left(3730^{\mathrm{d}}\right) \\
3040,3130,3850\end{array}$ & $2170-2080$ & $\begin{array}{c}1370\left(1510^{\mathrm{d}}\right), \\
1630,1720\end{array}$ & $2850-2700$ \\
\hline
\end{tabular}

${ }^{\mathrm{a}}$ Reference [12], ${ }^{\mathrm{b}}$ see Figure 3 and Section 3.2, ${ }^{\mathrm{c}}$ not detected, and ${ }^{\mathrm{d}}$ shoulder.

For $30 \mathrm{Fe}-\mathrm{Mg} 300$ and $30 \mathrm{Fe}-\mathrm{Mg} 200$ solids a minor $\mathrm{MgO}$ phase was observed together with the predominant $\mathrm{Mg}(\mathrm{OH})_{2}$ phase.

3.3. Fe-Supported Systems. By choosing $\mathrm{MgO}, \mathrm{TiO}_{2}$, and $\mathrm{SiO}_{2}$ to support iron oxide in this section, it was expected that the large variety of acid-base strengths of $\mathrm{MgO}$ (basic support), $\mathrm{TiO}_{2}$ (amphiprotic support), or $\mathrm{SiO}_{2}$ (acidic support) important in determining catalytic activity could be realized. In a previous work [12], we have shown that the most active system is the catalyst containing $\mathrm{MgO}$ as a support. $\mathrm{Fe}_{2} \mathrm{O}_{3} / \mathrm{MgO}$ is 12 times more active than $\mathrm{Fe}_{2} \mathrm{O}_{3} / \mathrm{TiO}_{2}, 21$ times more active than the unsupported catalyst, and 100 times more active than $\mathrm{Fe}_{2} \mathrm{O}_{3} / \mathrm{SiO}_{2}$.

The X-ray crystalline phases of the elaborated Fe-only, $30 \mathrm{Fe}-\mathrm{Mg}$, 30Fe-Ti, and $30 \mathrm{Fe}-\mathrm{Si}$ systems are given in Table 1 with the results of calorimetric and DRIFT measurements data. $\mathrm{MgFe}_{2} \mathrm{O}_{4}$ was identified with mainly $\mathrm{MgO}$ support phase in the 30Fe-Mg solid system. On the three other systems, iron was found at the $\mathrm{Fe}(3+)$ state in it $\alpha-\mathrm{Fe}_{2} \mathrm{O}_{3}$ allotropic variety (JCPDS number 89-0598).

3.3.1. Calorimetric Data. In order to establish correlation between catalytic activity and the acid-base properties of the catalyst surface, it is essential to determine the nature and the strength of the acid-base sites by adsorption of a probe molecule.

The differential heats of carbon dioxide adsorption, at $80^{\circ} \mathrm{C}$, versus coverage, are illustrated in Figure 4 . As can be seen from these illustrations, the evolution of the differential heat of carbon dioxide is strongly marked by the nature of the added support. $30 \mathrm{Fe}-\mathrm{Mg}$ sample shows evidence of a much larger amount of strong strength basic sites with an initial heat of adsorption of $150 \mathrm{~kJ} \cdot \mathrm{mol}^{-1}$ as indicated in Figure 4 by dark diamond-shaped symbols. This MgO modified solid exhibits a second population of strong strength of basic surface sites at around $130 \mathrm{~kJ} \cdot \mathrm{mol}^{-1}$ then a continual decrease of the strength of basic sites. The presence of the second population of basic sites can be attributed to bulk MgO $\left(\sim 120 \mathrm{~kJ} \cdot \mathrm{mol}^{-1}\right)$ in good agreement with XRD data (see Table 1). On 30Fe-Ti and $30 \mathrm{Fe}-\mathrm{Si}$ surfaces, we noted that the basicity strength declines rapidly by replacing $\mathrm{MgO}$ by $\mathrm{TiO}_{2}$ and $\mathrm{SiO}_{2}$, respectively. The acidic properties of $30 \mathrm{Fe}-\mathrm{Si}$ are confirmed by the results presented in Figure 5. Finally, the distribution of the strength of $\mathrm{CO}_{2}$ adsorption, that is, basicity, is strongly dependent

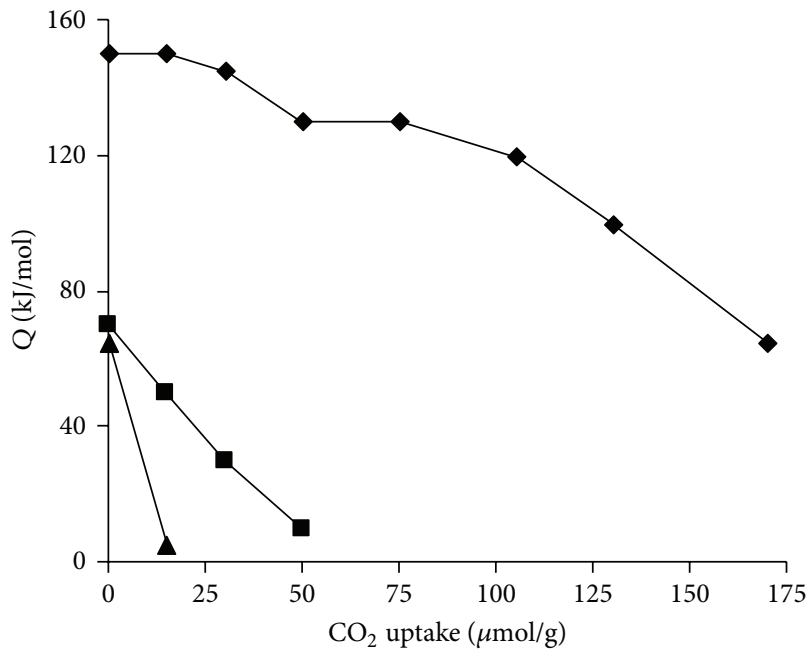

(a)

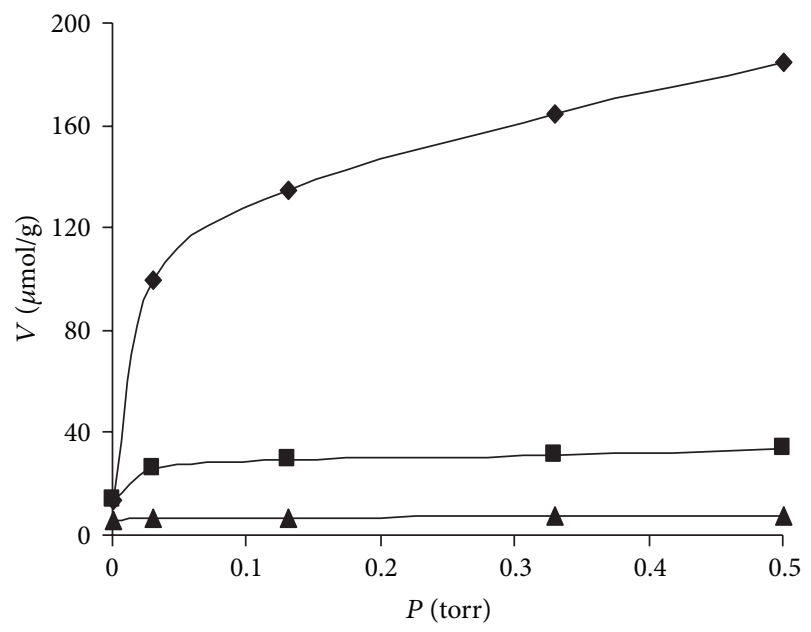

(b)

FIGURE 4: Differential heats of $\mathrm{CO}_{2}$ adsorption at $80^{\circ} \mathrm{C}$. ( $\left.\mathbf{\Delta}\right) 30 \mathrm{Fe}-\mathrm{Si}$, (匹) $30 \mathrm{Fe}-\mathrm{Ti}$, and $(\bullet) 30 \mathrm{Fe}-\mathrm{Mg}$.

on the nature of added support: $30 \mathrm{Fe}-\mathrm{Mg} \gg 30 \mathrm{Fe}-\mathrm{Ti}>\mathrm{Fe}-$ only $\gg 30 \mathrm{Fe}-\mathrm{Si}$.

3.3.2. DRIFTS Data. The DRIFTS data of Fe-only, 30Fe$\mathrm{Si}, 30 \mathrm{Fe}-\mathrm{Ti}$, and $30 \mathrm{Fe}-\mathrm{Mg}$ catalysts are presented in Table 1. The spectrum of $30 \mathrm{Fe}-\mathrm{Mg}$ reduced solid system shows, at 


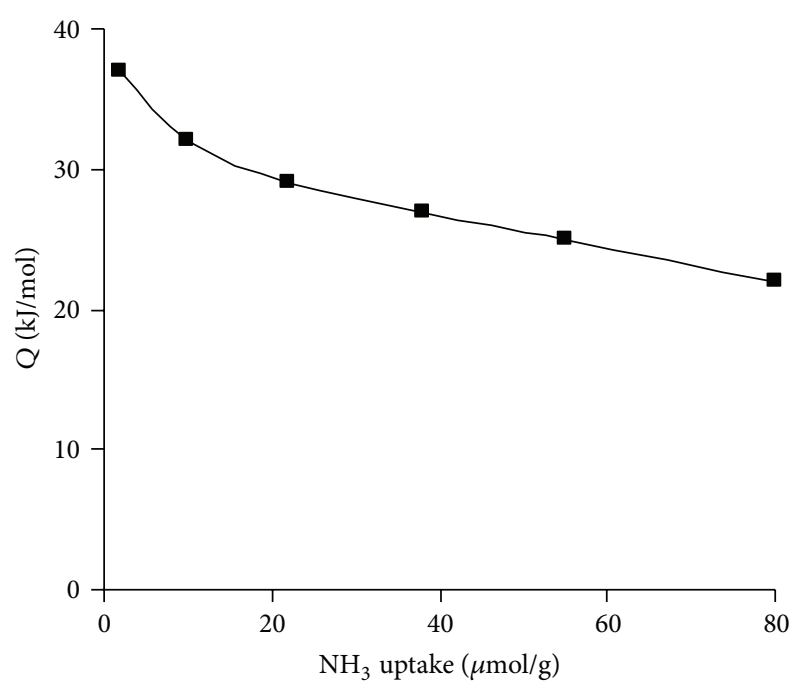

FIgURE 5: Differential heat of $\mathrm{NH}_{3}$ adsorption at $80^{\circ} \mathrm{C}$ of $30 \mathrm{Fe}-\mathrm{Si}$ sample.

the reaction temperature of $450^{\circ} \mathrm{C}$, a large adsorption band and its maximum at $3570 \mathrm{~cm}^{-1}$ (with a shoulder at 3730 $\mathrm{cm}^{-1}$ ) which is related to the interaction of $\mathrm{H}_{2} \mathrm{O}$ with the medium basic groups of $\mathrm{MgO}$ revealed by calorimetric study in Section 3.3.1:

$$
\mathrm{Mg}+\mathrm{H}_{2} \mathrm{O}_{(\mathrm{g})} \longrightarrow \mathrm{Mg}-\mathrm{OH}+\mathrm{Mg}-\mathrm{H}
$$

In addition to the large $\mathrm{OH}$ band abovementioned, other smaller band adsorbed species are detected in the range 3130$3040 \mathrm{~cm}^{-1}$. From this observation, it comes that these bands correspond to $\mathrm{Fe}(\mathrm{OH})$ still present even after reduction due to the remaining traces of $\mathrm{H}_{2} \mathrm{O}$ always present in the dynamic DRIFT cell.

Furthermore, the small bands emerging at 2170$2080 \mathrm{~cm}^{-1}$ are characteristic of the gaseous CO via the following reaction:

$$
\mathrm{Fe}+\mathrm{CO}_{(\mathrm{g})} \longrightarrow \mathrm{Fe}-\mathrm{CO}
$$

The doublet at the $2400-2330 \mathrm{~cm}^{-1}$ region corresponds to adsorbed and/or gaseous $\mathrm{CO}_{2}$.

Elsewhere, the dosing of the gas mixture $\mathrm{CO}+\mathrm{H}_{2} \mathrm{O}$ onto reduced $30 \mathrm{Fe}-\mathrm{Mg}$ produced formate adspecies (1720, 1630, and $1370 \mathrm{~cm}^{-1}$ ) as a surface intermediate:

$$
\mathrm{Fe}-\mathrm{CO}+\mathrm{Mg}-\mathrm{OH} \longrightarrow \mathrm{Mg}-\mathrm{HCOO}+\mathrm{Fe}
$$

The latter adsorbed species are considered as an active intermediate of the water-gas shift reaction process:

$$
\begin{gathered}
\mathrm{Mg}-\mathrm{HCOO} \longrightarrow \mathrm{CO}_{2(\mathrm{~g})}+\mathrm{Mg}-\mathrm{H} \\
2 \mathrm{Mg}-\mathrm{H} \longrightarrow \mathrm{H}_{2(\mathrm{~g})}+2 \mathrm{Mg}
\end{gathered}
$$

As opposed to $30 \mathrm{Fe}-\mathrm{Mg}$, no infrared contribution from formate adsorbed species was observed on the reduced $30 \mathrm{Fe}$ $\mathrm{Ti}$ system. After contacting this catalyst with $\mathrm{CO}+\mathrm{H}_{2} \mathrm{O}$ mixture gas, two new bands are detected in the carbonate species region $\left(1550-1630 \mathrm{~cm}^{-1}\right)$ with the doublet at $2170-$ $2080 \mathrm{~cm}^{-1}$, a characteristic of the CO gaseous (Table 1). Based on this observation, we can conclude that this system does not work like the $30 \mathrm{Fe}-\mathrm{Mg}$ basic catalyst in the water-gas shift reaction.

From the data in Table 1, one can see that no formate or carbonate bands were detected on the reduced $30 \mathrm{Fe}-\mathrm{Si}$ and Fe-only catalysts in line with Rethwisch and Dumesic works [1].

\section{Conclusion}

In this study, one can conclude that magnesium oxidemodified Fe, free from chromium samples, is a good catalyst for the high temperature shift reaction. By adding $\mathrm{MgO}$ to $\mathrm{Fe}_{2} \mathrm{O}_{3}$, a spinel oxide phase of type $\mathrm{MgFe}_{2} \mathrm{O}_{4}$, initially detected as a minor phase after calcinations at 200 and $300^{\circ} \mathrm{C}$, was reinforced and formed, at a temperature of calcination of $400^{\circ} \mathrm{C}$, one of the main crystallized phases. These results could indicate that the $\mathrm{MgFe}_{2} \mathrm{O}_{4}$ phase stabilizes the reduced iron phase, preventing its sintering under realistic WGSR conditions (high $\mathrm{H}_{2} \mathrm{O}$ partial pressures).

An associative mechanistic of the hydrogen production via the high temperature shift reaction was also developed on this type of catalyst.

\section{Conflict of Interests}

The authors declare that there is no conflict of interests regarding the publication of this paper.

\section{Acknowledgment}

The authors would like to acknowledge Dr. T. Bourezgue for his careful reading of the paper.

\section{References}

[1] D. G. Rethwisch and J. A. Dumesic, "The effects of metal-oxygen bond strength on properties of oxides: II. Water-gas shift over bulk oxides," Applied Catalysis, vol. 21, no. 1, pp. 97-109, 1986.

[2] D. C. Grenoble, M. M. Estadt, and D. F. Ollis, "The chemistry and catalysis of the water gas shift reaction. 1 . The kinetics over supported metal catalysts," Journal of Catalysis, vol. 67, no. 1, pp. 90-102, 1981.

[3] A. Boudjemaa, A. Auroux, S. Boumaza, M. Trari, O. Cherifi, and R. Bouarab, "Hydrogen production on iron-magnesium oxide in the high-temperature water-gas shift reaction," Reaction Kinetics and Catalysis Letters, vol. 98, no. 2, pp. 319-325, 2009.

[4] N. E. Amadeo and M. A. Laborde, "Hydrogen production from the low-temperature water-gas shift reaction: Kinetics and simulation of the industrial reactor," International Journal of Hydrogen Energy, vol. 20, no. 12, pp. 949-956, 1995.

[5] B. Aeijelts Averink Silberova, G. Mul, M. Makkee, and J. A. Moulijn, "DRIFTS study of the water-gas shift reaction over $\mathrm{Au} / \mathrm{Fe}_{2} \mathrm{O}_{3}$," Journal of Catalysis, vol. 243, no. 1, pp. 171-182, 2006. 
[6] Q. Fu, W. Deng, H. Saltsburg, and M. Flytzani-Stephanopoulos, "Activity and stability of low-content gold-cerium oxide catalysts for the water-gas shift reaction," Applied Catalysis B: Environmental, vol. 56, no. 1-2, pp. 57-68, 2005.

[7] A. Basinska, L. Kepenski, and F. Donka, "The effect of support on WGSR activity of ruthenium catalysts," Applied Catalysis A: General, vol. 183, pp. 143-153, 1999.

[8] A. M. Duarte de Farias, A. P. M. G. Barandas, R. F. Perez, and M. A. Fraga, "Water-gas shift reaction over magnesia-modified $\mathrm{Pt} / \mathrm{CeO}_{2}$ catalysts," Journal of Power Sources, vol. 165, no. 2, pp. 854-860, 2007.

[9] E. Chenu, G. Jacobs, A. C. Crawford et al., "Water-gas shift: An examination of Pt promoted $\mathrm{MgO}$ and tetragonal and monoclinic $\mathrm{ZrO}_{2}$ by in situ drifts," Applied Catalysis B: Environmental, vol. 59, no. 1-2, pp. 45-56, 2005.

[10] I. L. Júnior, J.-M. M. Millet, M. Aouine, and M. do Carmo Rangel, "The role of vanadium on the properties of iron based catalysts for the water gas shift reaction," Applied Catalysis A: General, vol. 283, no. 1-2, pp. 91-98, 2005.

[11] C. Martos, J. Dufour, and A. Ruiz, "Synthesis of $\mathrm{Fe}_{3} \mathrm{O}_{4}$-based catalysts for the high-temperature water gas shift reaction," International Journal of Hydrogen Energy, vol. 34, no. 10, pp. 4475-4481, 2009.

[12] A. Boudjemaa, C. Daniel, C. Mirodatos, M. Trari, A. Auroux, and R. Bouarab, "In situ DRIFTS studies of high-temperature water-gas shift reaction on chromium-free iron oxide catalysts," Comptes Rendus Chimie, vol. 14, no. 6, pp. 534-538, 2011.

[13] C. Rhodes, G. J. Hutchings, and A. M. Ward, "Water-gas shift reaction: finding the mechanistic boundary," Catalysis Today, vol. 23, no. 1, pp. 43-58, 1995.

[14] G. C. Chinchen, R. H. Logan, and M. S. Spencer, "Water-gas shift reaction over an iron oxide/chromium oxide catalyst. II: stability of activity," Applied Catalysis, vol. 12, no. 1, pp. 89-96, 1984.

[15] R. Bouarab, A. Boudjemaa, M. Trari, S. Bennici, and A. Auroux, "Influence du support sur la structure cristalline, les propriétés acido-basiques et l'activité des systèmes à base de fer en réaction $\mathrm{CO}+\mathrm{H}_{2} \mathrm{O}$," Comptes Rendus Chimie, vol. 12 , no. 3-4, pp. 527$532,2009$.

[16] W. M. Shaheen, A. A. Zahran, and G. A. El-Shobaky, "Surface and catalytic properties of $\mathrm{NiO} / \mathrm{MgO}$ system doped with $\mathrm{Fe}_{2} \mathrm{O}_{3}$," Colloids and Surfaces A: Physicochemical and Engineering Aspects, vol. 231, no. 1-3, pp. 51-65, 2003. 

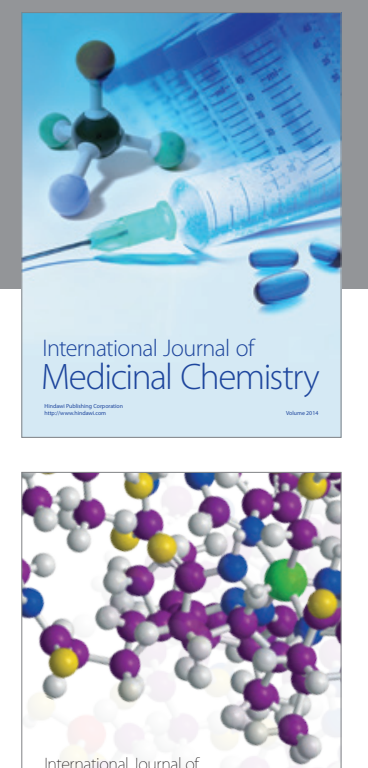

\section{Carbohydrate} Chemistry

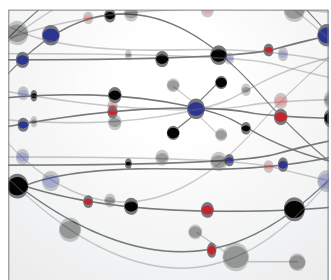

The Scientific World Journal
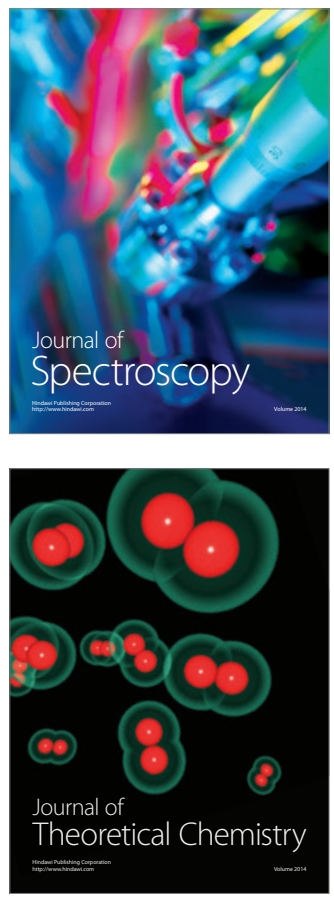
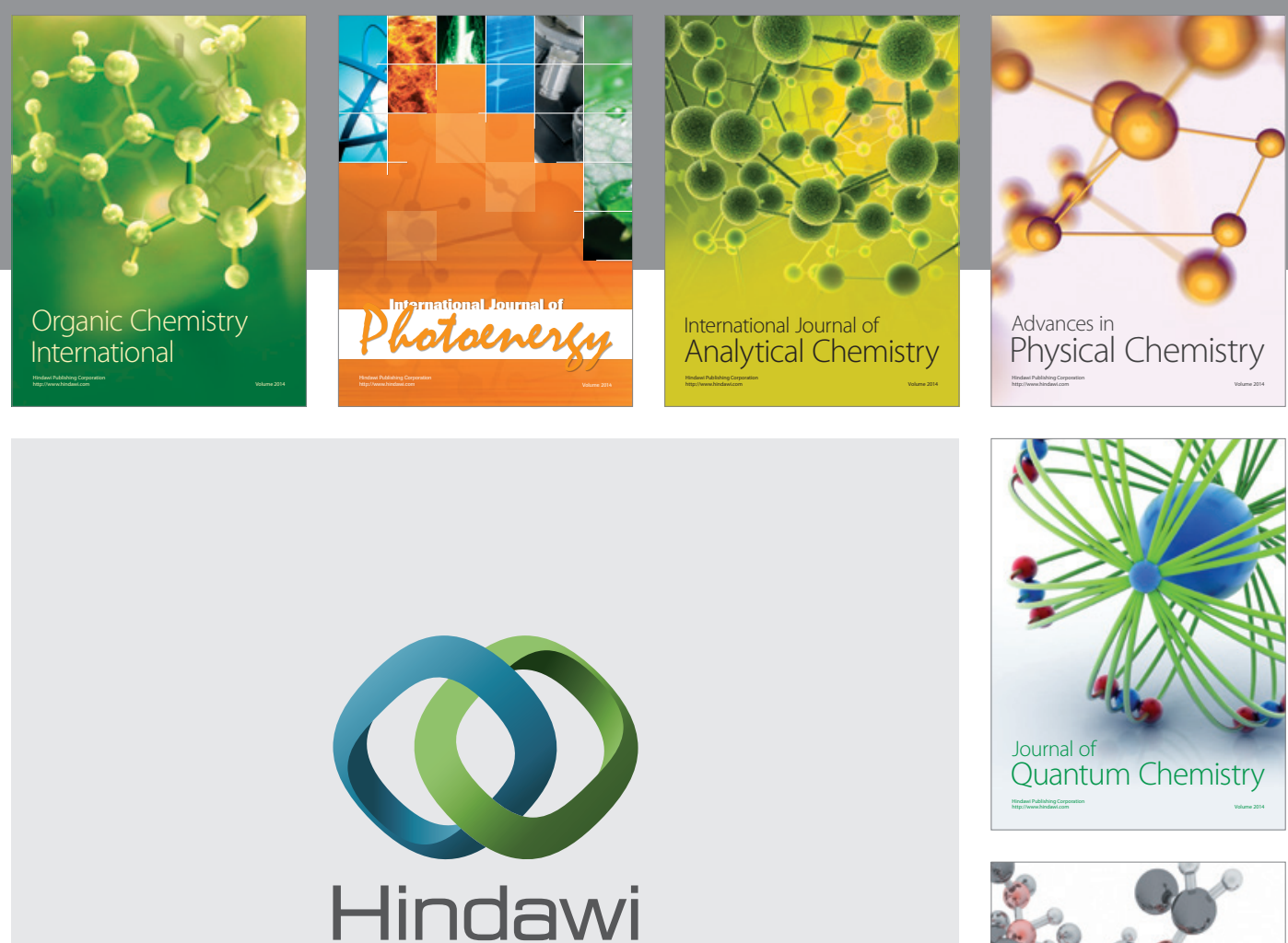

Submit your manuscripts at

http://www.hindawi.com

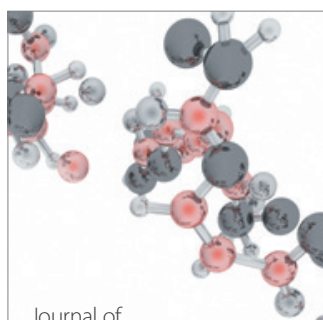

Analytical Methods

in Chemistry

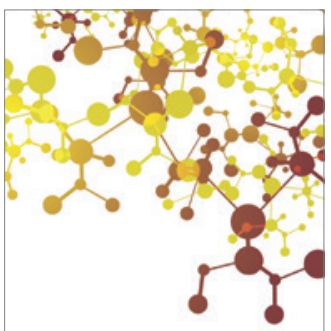

Journal of

Applied Chemistry

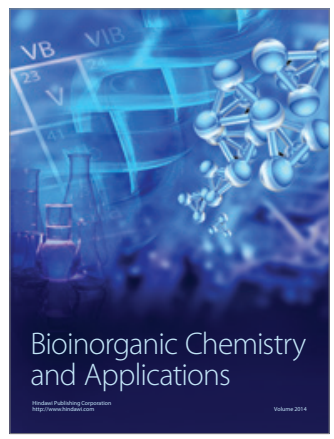

Inorganic Chemistry
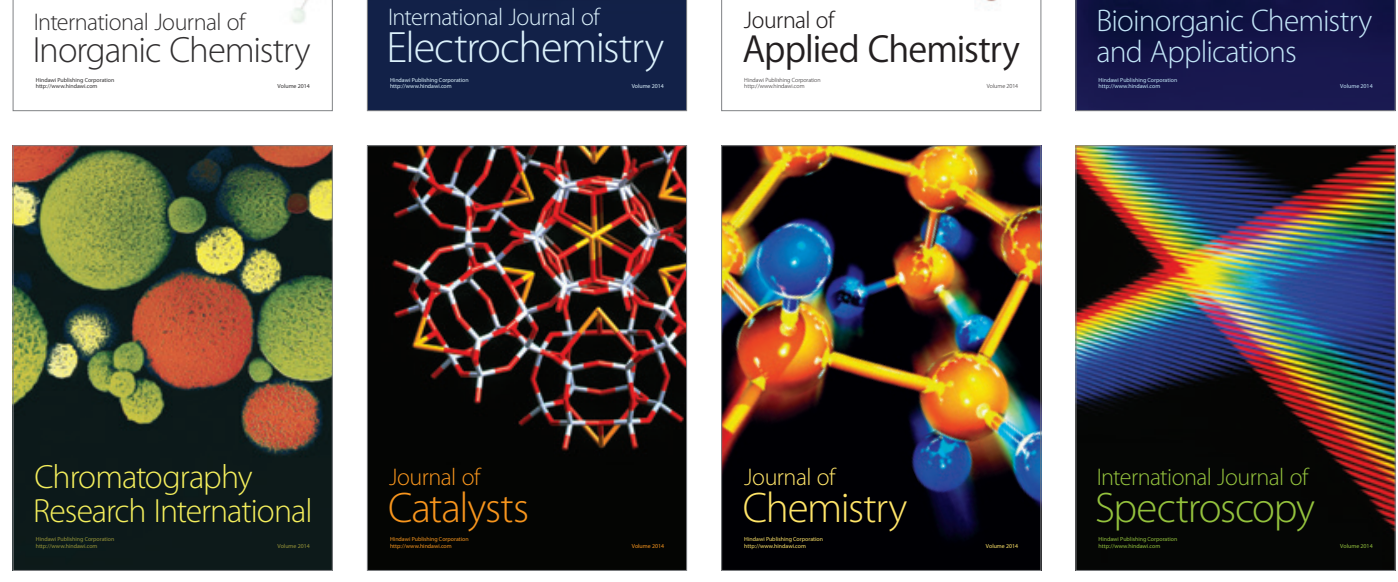